\title{
Timothy Daniels, Islamic Spectrum in Java
}

Surrey, UK: Ashgate, 2009. hbk. 210 pages

Timothy Daniels' Islamic Spectrum in Java critically examines the myriad of ways in which Javanese Muslims draw on religious and secular ideas to project desirable futures for their local societies, for the Indonesian nation, and for Indonesia's place in the global economic, political, and cultural structures of the twenty-first century. This book identifies a broad range of desirable futures projected by Javanese Muslims, as well as a range of beliefs and practices that comprise Javanese Islam (12). While this engaging work is very likely to appeal to scholars in many fields, theoretically and methodologically it is foremost an anthropological study. Synthesizing symbolic and cognitive anthropology in order to "provide "thick description" ${ }^{1}$ symbols . . . and to ascertain the social distribution of knowledge and formation of mental representations in various contexts (4)." Daniels draws primarily on ethnographic fieldwork conducted in the Yogyakarta area of south-central Java from 2003 to 2004. 
Daniels makes a complex argument, focusing on issues of globalization, localization, social change, identity formation, and the place of Islam in Javanese culture. He contends that in projecting a range of desirable futures, Javanese Muslims are able to negotiate globalization and directions of social change on their own terms by drawing from local culture and their interpretations of Islam in different ways. In particular, he examines to what extent particular ideological positions expressed by Javanese Muslims contribute to or undermine processes of equalization - "processes of weakening, undermining, and lessening hierarchical formations" (8). In supporting his argument, he addresses other related issues as well, including concepts of spiritual power, gender, sexuality, and class.

Islamic Spectrum in Java is tightly organized into an introduction, seven chapters, and a conclusion. In each of the seven chapters, Daniels focuses on different cultural forms. He supports his main argument in each chapter by analyzing how Javanese Muslims project particular desirable futures through these cultural forms as they draw on their culture and religion and thereby interact with globalization and equalization. For example, in Chapter 1, "City of Culture, Tourist Objects and Difference as Fetish," he analyzes government and palace-organized ceremonies, showing that "these events and their organizers" project a desirable future in which Indonesia, as a liberal democracy, more fully integrates "into the global capitalist system" and "accommodates . . . essential cultural flows from the developed world" while also "maintaining Islamic ideas and Javanese philosophy" (159). At the same time, he recognizes that "Local traditional beliefs and practices ... reinforce structures of inequality" (30).

Daniels dedicates other chapters to other cultural forms. Chapter 2, "Locating 'Islam' Between Thin Veneer and Normative Piety," centers on religious activities and rituals. Muslim healers and their practices are the subject of Chapter 3, "Dukun, Kyai and Ustadz: Healing along the Spectrum." In Chapter 4, "Social Drama, Dangdut and Popular Culture," Daniels analyzes debates concerning highly sexualized forms of dangdut, a genre of popular music. He turns to the activities and beliefs of the Muslim organization Muhammadiyah in Chapter 5, "Muslim Puritans, Cultural Dakwah and Reformation," and he then returns to performance in Chapter 6, "Student Theater, Social Critique and Equalization." Chapter 7, "Maiyah, Communitas and Common People," focuses on study sessions of a new religious movement. In the conclusion, he revisits the desirable futures identified in each chapter, delving further into the implications that these projections hold for processes of localization, globalization, and equalization. 
Much is to be admired about this fascinating study. Daniels clearly supports his main points using intelligent, accessible language. His thick descriptions, sensitive attention to local perspectives, and vivid writing bring the reader to Java and allow space for the voices of his interlocutors to be heard. He is also earnest about his own perspectives and relationships with the people he is consulting - using this honest self-reflexivity to support his arguments and strengthen his authority as a researcher who is personally and emotionally invested in Indonesia's future. (11) The nine figures, including a map of the Yogyakarta area and eight photographs by the author, further help to bring the reader to Java.

Furthermore, Daniels contributes to the study of Islam, showing that Muslims continuously negotiate their religious beliefs and practices, and in so doing, contribute to processes of social and cultural transformation. With his distinctive approach to a spectrum of desirable futures, Daniels productively pushes forward discussions concerning the place of Islam in Java, a subject of intense interest and debate among scholars of Indonesia. Building on Geertz's seminal and controversial book The Religion of Java (Chicago: University of Chicago Press, 1960), as well as scholarship that has since followed - including Mark Woodward's Islam in Java: Normative Piety and Mysticism in the Sultanate of Yogyakarta (Tucson, AZ: University of Arizona Press, 1989), Andrew Beatty's Varieties of Javanese Religion: An Anthropological Account (Cambridge, UK: Cambridge University Press, 1999), and Robert Hefner's Civil Islam: Muslims and Democratization in Indonesia (Princeton, NJ: Princeton University Press, 2000) - Daniels shows that many kinds of Javanese Muslims actively participate in the continuous production of Javanese and Indonesian culture.

This book is valuable in many ways. It is particularly relevant and productive for those concerned with cultural politics in Reformation Era Indonesia (1998 to the present) - a time that, following the three-decade authoritarian reign of Suharto and the New Order regime (1966-1998), has seen dramatic political, social, and economic transformations. At 168 pages of main text, the book is feasible to assign in graduate or upper division undergraduate seminars in anthropology, Southeast Asian studies, religious studies, or related fields. A glossary and index help to make the book more accessible and user-friendly. Individual chapters would enrich units or courses concerning particular cultural forms. For example, Chapter 5 on Muhammadiyah and Chapter 7 on Maiyah would fuel discussions of religious movements, while Chapter 4 on dangdut would enliven discussions of popular music, popular culture, gender, and the body. With his stimulat- 
ing approach and critical, nuanced perspectives on localization, globalization, equalization, and Javanese Islam, Timothy Daniels has given scholars and students much to digest and debate for years to come.

\section{Endnotes}

1. Clifford Geertz, The Interpretation of Cultures (New York: Basic Books, 1973).

Christina Sunardi Assistant Professor University of Washington School of Music

Box 353450

Seattle, WA 98195-3450 csunardi@u.washington.edu 